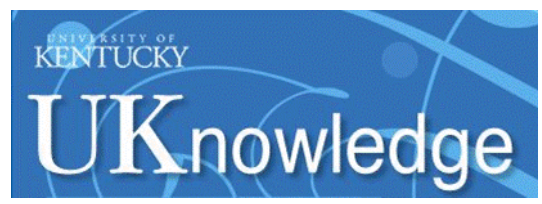

University of Kentucky

UKnowledge

3-2014

\title{
What Kind of Seed Dormancy Might Palms Have?
}

Jerry M. Baskin

University of Kentucky, jerry.baskin@uky.edu

Carol C. Baskin

University of Kentucky, ccbask0@uky.edu

Follow this and additional works at: https://uknowledge.uky.edu/biology_facpub

Part of the Biology Commons, and the Plant Sciences Commons

Right click to open a feedback form in a new tab to let us know how this document benefits you.

\section{Repository Citation}

Baskin, Jerry M. and Baskin, Carol C., "What Kind of Seed Dormancy Might Palms Have?" (2014). Biology Faculty Publications. 49.

https://uknowledge.uky.edu/biology_facpub/49

This Article is brought to you for free and open access by the Biology at UKnowledge. It has been accepted for inclusion in Biology Faculty Publications by an authorized administrator of UKnowledge. For more information, please contact UKnowledge@lsv.uky.edu. 


\section{What Kind of Seed Dormancy Might Palms Have?}

\section{Digital Object Identifier (DOI)}

http://dx.doi.org/10.1017/S0960258513000342

\section{Notes/Citation Information}

Published in Seed Science Research, v. 24, issue 1, p. 17-22.

(c) Cambridge University Press 2013.

The copyright holder has granted the permission for posting the article here. 


\section{Seed Science Research}

http://journals.cambridge.org/SSR

Additional services for Seed Science Research:

Email alerts: Click here

Subscriptions: Click here

Commercial reprints: Click here

Terms of use : $\underline{\text { Click here }}$

\section{What kind of seed dormancy might palms have?}

Jerry M. Baskin and Carol C. Baskin

Seed Science Research / Volume 24 / Issue 01 / March 2014, pp 17 - 22

DOI: 10.1017/S0960258513000342, Published online: 18 December 2013

Link to this article: http://journals.cambridge.org/abstract S0960258513000342

How to cite this article:

Jerry M. Baskin and Carol C. Baskin (2014). What kind of seed dormancy might palms have? . Seed Science Research, 24, pp 17-22 doi:10.1017/S0960258513000342

Request Permissions : $\underline{\text { Click here }}$ 


\title{
RESEARCH OPINION
}

\section{What kind of seed dormancy might palms have?}

\author{
Jerry M. Baskin ${ }^{1}$ and Carol C. Baskin ${ }^{1,2 *}$ \\ ${ }^{1}$ Department of Biology, University of Kentucky, Lexington, KY 40506-0225, USA; ${ }^{2}$ Department of Plant and Soil \\ Sciences, University of Kentucky, Lexington, KY 40546-0312, USA
}

(Received 16 July 2013; accepted after revision 5 November 2013; first published online 18 December 2013)

\begin{abstract}
Palm diaspores are reported to have various kinds of dormancy. However, (1) the embryo is underdeveloped; (2) the endocarp is water permeable; and (3) the diaspores take a long time to germinate. Thus, we conclude that the diaspores of the majority of palm species have morphophysiological dormancy (MPD). The ones that do not have MPD are morphologically dormant.
\end{abstract}

Keywords: Arecaceae, embryonic axis (inside cotyledonary petiole), endocarp germination pore ('eye'), haustorium (cotyledonary blade), hypogeal germination, morphological dormancy, morphophysiological dormancy, operculum, underdeveloped embryo

\section{Introduction}

The palm family (Arecaceae) includes about 2400-2600 species of evergreen trees, shrubs and lianas, most of which occur in the tropics and subtropics (Corner, 1966; Moore and Uhl, 1973; Uhl and Dransfield, 1987; Tomlinson, 1990; Mabberley, 2008). Various kinds of dormancy have been assigned to the diaspores (seeds or fruits) of this family, including physical (Carpenter et al., 1993; Moussa et al., 1998), non-absolute physical (Neves et al., 2013), physiological (Ribeiro et al., 2011), non-profound physiological (Ribeiro et al., 2012b; Neves et al., 2013; Megalhães et al., 2013), non-deep physiological (Junior et al., 2013; Schlindwein et al., 2013), morphological, morphological combined with chemical, morphological combined with mechanical, morphological combined with both mechanical and

*Correspondence

Email: ccbask0@uky.edu non-deep physiological (Nikolaeva et al., 1985), mechanical exogenous (Fior et al., 2011) and morphophysiological (Perez et al., 2008). Thus, it seems that much confusion exists concerning the kind(s) of diaspore dormancy in the Arecaceae. The purpose of this opinion paper is to evaluate the literature on palm seeds and their germination in order to determine to which dormancy class(es) (sensu Baskin and Baskin, 2004) they might belong.

\section{Results and discussion}

Palm fruits are berries or fibrous drupes with up to ten seeds. However, in many species there is only one seed per mature fruit, although the ovary is tricarpellate. The fruits exhibit a wide range of sizes, the largest being that of the double coconut Lodoicea maldivica (c. $45-50 \mathrm{~cm}$ long and weighing $36 \mathrm{~kg}$ ), which has the largest seed in the plant kingdom. Generally, the fruit wall (pericarp) consists of the exocarp, mesocarp and endocarp. The endocarp or 'shell' may be thick and stoney (drupe) to thin, papery or fleshy (berry); in some taxa, it is undifferentiated (Corner, 1966; Harper et al., 1970; Moore and Uhl, 1973; Uhl and Dransfield, 1987; Tomlinson, 1990; Dransfield and Uhl, 1998).

The seed consists of an achlorophyllous embryo and endosperm surrounded by a thin (usually) seed coat and sometimes a sarcotesta (fleshy outer seed coat). In most species, the embryo is small and linear, but in some species, e.g. Nypa fruticosa (see figure B.51 in Tomlinson, 1986), the only palm that is a 'strict or true mangrove species', it is shaped like a cylinder, being flat on one end and tapering to a point on the other end. In general, the embryo (E):seed (S) length (E:S) ratio is low, i.e. $<0.10$ to $c$. $0.30-0.40$. However, in a few genera the embryo is large, e.g. E:S ratio of c. 0.70 in Oenocarpus and c. 0.85 in Jessenia [E:S ratios determined by measuring lengths of seeds and embryos from drawings in Uhl and Dransfield (1987)]. 
The embryo may occupy $<1 \%$ of the total seed volume, and its position can be basal (micropylar end), apical (other end), lateral or some variation thereof, e.g. subapical. In seeds with thick endocarps, such as those of coconut palm and oil palm, the embryo is located adjacent to an endocarp germination pore ('eye') (Fig. 1a). Seed storage behaviour can be orthodox or non-orthodox (intermediate or recalcitrant) (Corner, 1966; Yakovlev and Zhukova, 1980; Janzen, 1982; Uhl and Dransfield, 1987; Tomlinson, 1990; Ellis et al., 1991; Orozco-Segovia et al., 2003; Panza et al., 2004; Pritchard et al., 2004; Von Fintel et al., 2004; González-Benito et al., 2006; Perez et al., 2008; Ribeiro et al., 2011, 2012a, b; Jose et al., 2012).

In whole-view (Fig. 1a), the embryo can be divided into two regions: cotyledonary petiole located adjacent to the operculum [portion of endosperm (micropylar endosperm) and seed coat covering the proximal end of embryo that may be demarcated by a zone of weakness] and cotyledon blade, which remains inside the seed. The endosperm is homogeneous or ruminate, and in some species it contains a cavity that is dry or filled with liquid, e.g. coconut 'milk' in Cocus nucifera
(Hussey, 1958; Corner, 1966; Robertson, 1977; DeMason, 1985; Uhl and Dransfield, 1987; DeMason et al., 1989; Aguiar and de Mendonça, 2002; Neves et al., 2013). The cotyledonary blade or apical portion thereof acts as a haustorium and absorbs and metabolizes products of hydrolysis from the endosperm; however, see Panza et al. (2004), who concluded that the endosperm of the recalcitrant species Euterpe edulis is inactive, i.e. no storage metabolism. Histologically, the embryo consists of a single cotyledon and a short plumular-radicular axis (epicotyl with leaf primordia and root apex) located in the proximal end of the cotyledonary tube (Fig. 1b) (Dassanayake and Sivakadachchan, 1973; Robertson, 1976; Haccius and Philip, 1979; DeMason, 1988a; Aguiar and de Mendonça, 2003; Panza et al., 2004; Henderson, 2006; Ribeiro et al., 2012a; Nazario et al., 2013; Neves et al., 2013).

In some palms, the natural dispersal unit is a drupe with a hard, thick endocarp from which the seeds can be removed only by physically cracking it (Robertson and Small, 1977; Broschat, 1998; Davies and Pritchard, 1998; Moussa et al., 1998; Ehara et al., 2001; Perez et al., 2008; Myint et al., 2010; Ribeiro et al., 2011; Neves et al., 2013).
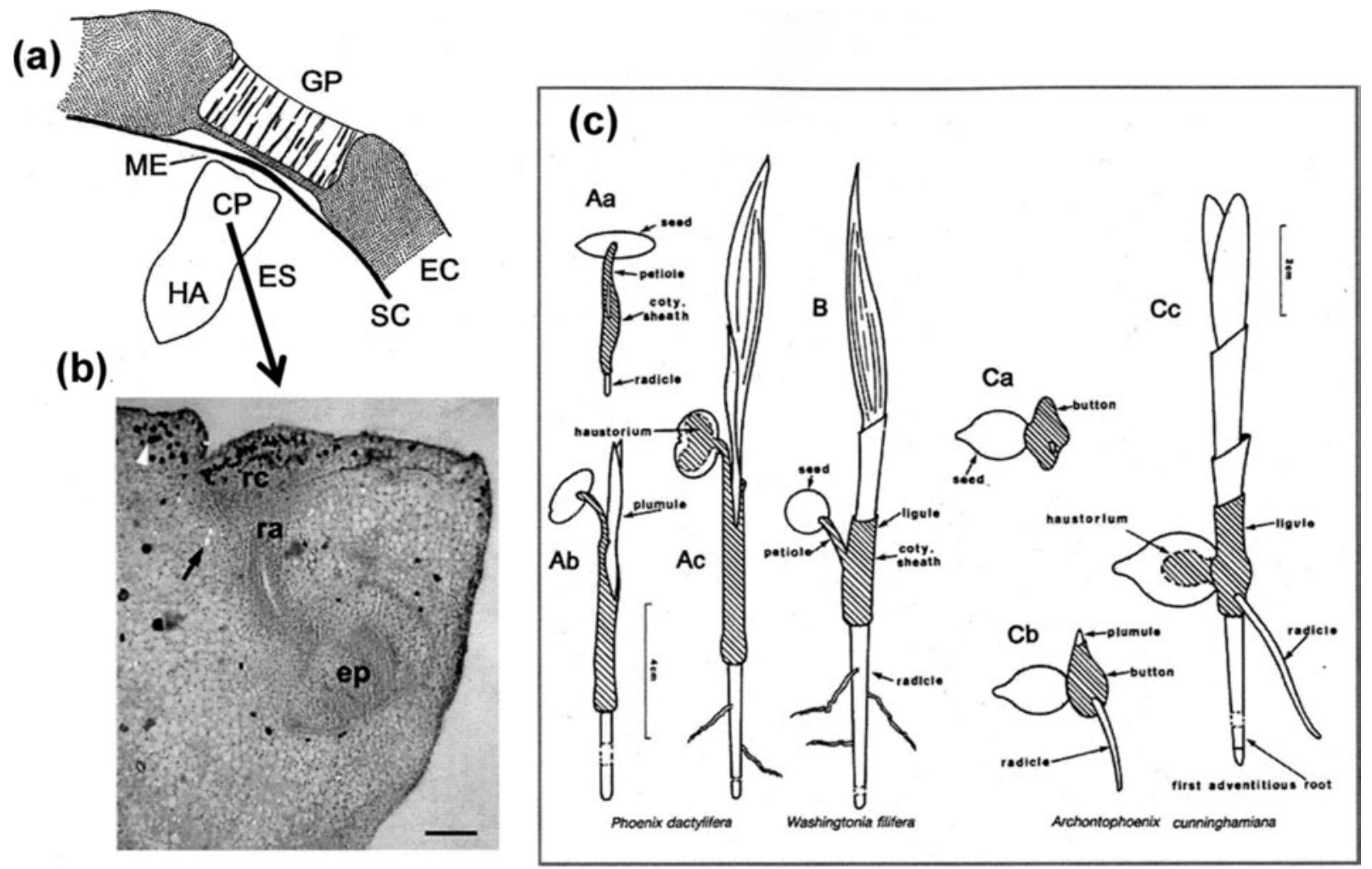

Figure 1. (a) Longitudinal section of a palm fruit showing embryo with cotyledonary petiole adjacent to the operculum (micropylar endosperm + seed coat) under the germination pore of a drupe of a palm. The embryo is about $3 \mathrm{~mm}$ long (from Hussey, 1958). (b) Median longitudinal section of proximal region of cotyledonary petiole showing embryonic axis (ep, ra, rc) that is enclosed within it. Scale bar is $0.20 \mathrm{~mm}$ (from Panza et al., 2004). (c) The three primary morphological types of seedlings (germination) commonly recognized in palms (from Tomlinson, 1960). Aa, Ab, Ac, remote-tubular; B, remote-ligular; Ca, Cb, Cc, adjacent-ligular. CP, cotyledonary petiole; EC, endocarp; ep, epicotyl; ES, endosperm; GP, germination pore with fibrous mesocarp tissue; HA, haustorium; ME, micropylar endosperm (endosperm cap); ra, radicle; rc, root cap; SC, seed coat. Figures reproduced with permission. 
In most cases, presence of a hard endocarp inhibits seed germination. Thus, isolated seeds (removed from endocarp) germinate better, often much better (higher percentage/rate), than those with the pericarp intact (Broschat, 1998; Moussa et al., 1998; Ferreira and Gentil, 2006; Perez et al., 2008; Ribeiro et al., 2011). As such, claims have been made that the fruit is water impermeable, thus accounting for the 'physical dormancy' of the diaspore, i.e. drupe (Carpenter et al., 1993; Moussa et al., 1998). However, this is not the case. Robertson and Small (1977) showed that the hard, thick pericarp of Jubaeopsis caffra was permeable to water (and oxygen), and Perez et al. (2008) demonstrated that imbibition of seeds inside fruits of Pritchardia remota was not blocked. The water content of isolated seeds of Acrocomia aculeata did not differ significantly from that of intact fruits with a thick, stony endocarp (21.7 and $22.9 \%$, respectively) after $60 \mathrm{~d}$ on a moist substrate (Ribeiro et al., 2011). After $45 \mathrm{~d}$ of imbibition, the percentage moisture content (MC) of isolated seeds, seeds in intact fruits and seeds inside scarified fruits of Attalea vitrivir was nearly identical; seed MC increased from c. $6-7 \%$ to c. $22-23 \%$ (Neves et al., 2013).

We consider the embryo in palm seeds to be underdeveloped. The proximal end of the embryo, i.e. the cotyledonary petiole, is adjacent to the operculum, and germination of palm seeds is often defined as dislodgment of the operculum resulting from elongation of the cotyledonary petiole (Fong, 1978; Perez et al., 2008; Fior et al., 2011; Ribeiro et al., 2011; Neves et al., 2013). Further, the cotyledonary blade (haustorium) expands to fill most of the seed, albeit after the cotyledonary petiole emerges from the seed (germination), i.e. expansion of the cotyledon/ haustorium occurs and tissue development continues following germination (DeMason, 1984, 1985, 1988b). In which case, germination occurs before emergence of the radicle and shoot from the cotyledonary petiole/sheath and after the latter has protruded through the opening left by displacement of the operculum. Thus, the embryo requires further development outside the seed before germination in the strict sense of the word (i.e. radicle emergence) is complete. In fact, de Queiroz (1986) defined the germination in seeds of Euterpe edulis as occurring in two distinct stages: (1) protrusion of the cotyledonary petiole, and (2) growth (emergence) of the radicle and shoot from the cotyledonary petiole, which he described as 'the germination itself'. He found that the second stage was completed about 6 weeks after the first stage. The whole-seed germination process in palms, as described by Pinheiro (2001) for Schippia concolor, in which germination is a variation of the two remote types described below, begins with protrusion of the cotyledonary petiole and ends with emergence of the plumule through the base of the cotyledonary sheath. In S. concolor, the cotyledonary petiole emerges from the (isolated) seed 8-9 d after planting, and the root and plumule from the cotyledonary petiole about 30 and $80-90 \mathrm{~d}$, respectively, after planting. In the mangrove species Nypa fruticans, germination is 'incipiently viviparous' (Tomlinson, 1986).

In a review of information on time to germination in palms [unit(s) of germination not specified, i.e. whole fruit, seed + endocarp ('nut') or seed ('kernel')] that included 1281 published records on 457 species, seeds in about $10 \%$ of the observations germinated within $30 \mathrm{~d}$, and for the other $90 \%$ time to germination ranged from between 31 and 40 to $1941 \mathrm{~d}$. Seeds in about $53 \%$ of the 1241 observations germinated between days 31 and 40 to 121-130 (Orozco-Segovia et al., 2003). The facts that seeds (diaspores) of most palms take longer than $30 \mathrm{~d}$ (usually much longer) to germinate and have underdeveloped embryos indicate that morphophysiological dormancy (MPD) is the major dormancy class in the family. The $10 \%$ of the diaspores that germinated in $\leq 30 \mathrm{~d}$ would have morphological dormancy (MD) (Baskin and Baskin, 2004).

All palms have hypogeal germination since the seed is not raised above the soil; in monocots with epigeal germination, the seed is raised above the soil surface by elongation of the cotyledon (Tillich, 2007). Three morphological types of seedlings (germination) are commonly recognized in palms: remote-tubular, remote-ligular and adjacent-ligular (Fig. 1c). In the latter two types, the cotyledonary petiole bears a ligule, a distal projection of the leaf sheath. In remote-tubular (e.g. Phoenix) and remote-ligular (e.g. Sabal, Washingtonia) types of germination, the embryonic axis (inside the cotyledonary tube/sheath) is pushed into the soil to varying depths by downward extension (positive geotropism) of the cotyledonary petiole with an enlarged basal sheath from which the seedling develops at varying distances from the seed. The persistent radicle (primary root) breaks through the base of the cotyledonary sheath, and the plumule emerges from the cleft in the cotyledonary sheath in the remote-tubular type and from the mouth of the cotyledonary sheath (ligular extension) in the remoteligular type. Thus, in these two types of germination the seedling is moved some distance from the seed, hence 'remote'. In the adjacent-ligular type (e.g. Archontophoenix), the cotyledonary tube elongates very little at germination, forming a 'button' or mass of tissue just outside the seed, from which the radicle and shoot emerge next to the seed, hence 'adjacent' (Tomlinson, 1960, 1990; Corner, 1966; Jordan, 1970; Moore and Uhl, 1973; Brown, 1976; Fong, 1978; Uhl and Dransfield, 1987; Henderson, 2006; Tahir et al., 2007). Henderson (2006) has pointed out that these three germination types are not completely satisfactory because of the great variation in length attained by the petiole in developed seedlings. Some modifications of these three basic germination types have been described by Tomlinson $(1960,1990)$ and Pinheiro (2001). 
The germination type is related to the internal structure of the embryo. In remote-tubular germination, the plumular-radicular axis is straight with respect to the cotyledon axis, the embryo is straight, the cotyledon elongates and the radicle is persistent. The plumularradicular axis is oblique with respect to the cotyledon axis in the remote-ligular type, the embryo is straight, the cotyledon elongates and the radicle is persistent. In the adjacent-ligular type, the plumular-radicular axis is at an obtuse angle with respect to the cotyledon axis, the embryo is curved, the cotyledon does not elongate and the radicle is not persistent; soon after germination, the radicle is replaced by adventitious roots (Tomlinson, 1960; Henderson, 2006).

Thus, it might be expected that the embryo does not fit the standard definition of an underdeveloped embryo, i.e. the embryo must grow inside the seed before the radicle emerges (Baskin and Baskin, 2004). However, Perez et al. (2008) showed that the length of the embryo of $P$. remota must increase 1.6-fold to displace the operculum, i.e. for the seed to germinate. Furthermore, radicle emergence, a standard definition for germination, does not occur in palms until after the embryo has definitely grown. Of the seven genera and nine species of palms included in their compilation of the kinds of seed dormancy in seed plants, Nikolaeva et al. (1985) listed them as having either morphological dormancy (6), a combination of morphological dormancy and chemical dormancy $\left(\mathrm{A}_{1}-6\right)$, a combination of morphological dormancy and mechanical dormancy $\left(A_{2}-6\right)$ or a combination of morphological dormancy, mechanical dormancy and non-deep physiological dormancy $\left(\mathrm{A}_{2}-6-\mathrm{B}_{1}\right)$. Nikolaeva (1999) stated that palms '... exhibit the morphological type of dormancy'.

The rejection of palm seeds as having MD (or MPD) by some investigators (e.g. Ribeiro et al., 2012a; Megalhães et al., 2013; Nazario et al., 2013) is based on the fact that seeds will germinate before the hypocotylradicle is fully differentiated or that the embryo is fully differentiated histologically. Ribeiro et al. (2012a) stated that seeds of $A$. aculeata did not have morphological dormancy '.. because the intermediary degree of differentiation [of the meristematic tissues] of the embryo does not restrict its germination...'. Nazario et al. (2013) concluded that the seeds of Bactris gasipaes do not have morphological dormancy because the embryo is fully differentiated histologically. Corner (1966) thought that palm seeds '... have little power of dormancy...', since tissue development continues in the anatomically immature embryo of mature seeds while germination is arrested. This way of thinking about MD (and MPD) differs from the traditional meaning of that (these) class(es) of seed dormancy (see above).

Thus, in the second edition of Seeds: ecology, biogeography, and evolution of dormancy and germination (Baskin and Baskin, in press) we have assigned seeds of all palms included in our survey of kinds of dormancy in the various vegetation zones on Earth to either MD or MPD. A caveat here is that decisions about assignment to either MD or MPD may be based on results of the responses of isolated seeds rather than on those of seeds within the natural germination unit, i.e. in some cases a drupe with a hard endocarp. In the literature on palm germination, the word 'seed' is often used for seed + endocarp (Corner, 1966; Tomlinson, 1990). Thus, since the drupe endocarp has been shown to inhibit germination of seeds inside them, some of our assignments to MD may be a case of diaspore (fruit) MPD. In other words, the seed freed from the fruit may exhibit $\mathrm{MD}$ and the natural germination unit MPD. An example of this is found in P. remota, in which the isolated seeds germinated much faster than the drupes (Perez et al., 2008). We agree with Perez (2009) who concluded that most palm diaspores have MPD.

It should be pointed out, however, that isolated seeds of some palm species may exhibit MPD, i.e. those isolated from fruits with a thick stoney endocarp (Hussey, 1958; Broschat, 1998; Wood and Pritchard, 2003; Ribeiro et al., 2011; Neves et al., 2013) or from those with a thin membranous endocarp (Carpenter, 1987, 1988). In addition, the operculum has been shown to inhibit germination of isolated palm seeds, and thus its removal promoted germination (Carpenter et al., 1993; Perez et al., 2008; Fior et al., 2011; Ribeiro et al., 2011). In $A$. aculeata, the micropylar endosperm (endosperm cap) part of the operculum (i.e. seed coat portion of operculum removed) was inhibitory to germination (Ribeiro et al., 2011).

Isolated embryos of palms have been reported to be non-dormant (Hussey, 1958; Ribeiro et al., 2011, 2012a). However, since removal of the endocarp, operculum or endocarp and operculum (see references above) and gibberellic acid $\left(\mathrm{GA}_{3}\right)$ treatment (Nagao and Sakai, 1979; Nagao et al., 1980; Roberto and Habermann, 2010; Ribeiro et al., 2011; Neves et al., 2013) promote germination, it seems likely that the embryo is not completely non-dormant, i.e. it has low growth potential and thus some degree of physiological dormancy. $\mathrm{GA}_{3}$ would be expected to promote germination in palm seeds by increasing the growth potential of the embryo and also by weakening the resistance of the (living) micropylar endosperm covering the proximal end of the cotyledonary petiole. Abscisic acid (ABA) also would be expected to play a role in palm diaspore dormancy by inhibiting the growth potential of the embryo and by weakening of the endosperm cap (da Silva et al., 2004; Finch-Savage and Leubner-Metzger, 2006). With regard to germination of oil palm seeds, Hussey (1958) stated that '... rupture of the operculum appears to be dependent upon intercellular breakdown in the abscission layer [of the micropylar endosperm] as well as on growth pressure of the embryo'. Jiménez et al. (2008) found that a sharp reduction in concentration of $\mathrm{ABA}$ in the 
embryo of oil palm was correlated with dormancy break (heat treatment). However, changes in concentration of GAs and other plant growth regulators could not be related to release of dormancy. Much remains to be learned about germination of palm diaspores, both at the whole-seed and biochemical-molecular levels.

\section{Conflict of interest}

None.

\section{References}

Aguiar, M.O. and de Mendonça, M.S. (2002) Aspectos morfo-anatomicos do embriao de Euterpe precatoria Mart. durante o processo germinativo. Acta Botanica Brasilica 16, 241-249.

Aguiar, M.O. and de Mendonça, M.S. (2003) Morfoanatomia da semente de Euterpe precatoria Mart. (Palmae). Revista Brasileira de Sementes 25, 37-42.

Baskin, C.C. and Baskin, J.M. Seeds: ecology, biogeography, and evolution of dormancy and germination (2nd edition). San Diego, Academic Press/Elsevier (in press).

Baskin, J.M. and Baskin, C.C. (2004) A classification system for seed dormancy. Seed Science Research 14, 1-16.

Broschat, T.K. (1998) Endocarp removal enhances Butia capitata (Mart.) Becc. (pindo palm) seed germination. HortTechnology 8, 586-587.

Brown, K.E. (1976) Ecological studies of the cabbage palm, Sabal palmetto. III. Seed germination and seedling establishment. Principes 20, 98-115.

Carpenter, W.J. (1987) Temperature and imbibition effects on seed germination of Sabal palmetto and Serenoa repens. HortScience 22, 660.

Carpenter, W.J. (1988) Temperature affects seed germination of four Florida palm species. HortScience 23, 336-337.

Carpenter, W.J., Ostmark, E.R. and Cornell, J.A. (1993) Embryo cap removal and high-temperature exposure stimulate rapid germination of needle palm seeds. HortScience 28, 904-907.

Corner, E.J.H. (1966) The natural history of palms. Berkeley, University of California Press.

da Silva, E.A.A., Toorop, P.E., van Aelst, A.C. and Hilhorst, H.W.M. (2004) Abscisic acid controls embryo growth potential and endosperm cap weakening during coffee (Coffea arabica cv. Rubi) seed germination. Planta 220, $251-261$.

Dassanayake, M.D. and Sivakadachchan, B. (1973) Germination and seedling structure of Borassus flabellifer. Ceylon Journal of Science (Biological Sciences) 10, 157-166.

Davies, R.I. and Pritchard, H.W. (1998) Seed storage and germination of the palms Hyphaene thebaica, H. petersiana and Medemia argun. Seed Science and Technology 26, 823-828.

DeMason, D.A. (1984) Growth parameters in the cotyledon of date seedlings. Botanical Gazette 145, 176-183.

DeMason, D.A. (1985) Histochemical and ultrastructural changes in the haustorium of date (Phoenix dactylifera L.). Protoplasma 126, 168-177.

DeMason, D.A. (1988a) Embryo structure and storage reserve histochemistry in the palm Washingtonia filifera. American Journal of Botany 75, 330-337.
DeMason, D.A. (1988b) Seedling development in Washingtonia filifera (Arecaceae). Botanical Gazette 149, 45-56.

DeMason, D.A., Stillman, J.I. and Ellmore, G.S. (1989) Acid phosphatase localization in seedling tissues of the palms, Phoenix dactylifera and Washingtonia filifera, and its relevance to controls of germination. Canadian Journal of Botany 67, 1103-1110.

de Queiroz, M.H. (1986) Botão germinativo do palmiteiro como indicator da germinaçao. Revista Brasileira de Sementes 2, 55-59.

Dransfield, J. and Uhl, N.W. (1998) Palmae. pp. 306-389 in Kubitzki, K. (Ed.) The families and genera of vascular plants. Flowering plants. Monocotyledons: Alismatanae and Commelinanae. Berlin, Springer-Verlag.

Ehara, H., Morita, O., Komada, C. and Goto, M. (2001) Effect of physical treatment and presence of the pericarp and sarcotesta on seed germination in sago palm (Metroxylon sagu Rottb.). Seed Science and Technology 29, 83-90.

Ellis, R.H., Hong, T.D., Roberts, E.H. and Soetisna, U. (1991) Seed storage behaviour in Elaeis guineensis. Seed Science Research 1, 99-104.

Ferreira, S.A.N. and Gentil, D.F.O. (2006) Extração, embebição e germinacao de sementes de tucumã (Astrocaryum aculeatum). Acta Amazonica 36, 141-146.

Finch-Savage, W.E. and Leubner-Metzger, G. (2006) Seed dormancy and the control of germination. New Phytologist 171, 501-523.

Fior, C.S., Rodrigues, L.R., Leonhardt, C. and Schwarz, S.F. (2011) Superacao de dormência em sementes de Butia capitata. Ciencia Rural, Santa Maria 41, 1150-1153.

Fong, F.W. (1978) Mode of germination in Eugeissona tristis Griff. Principes 22, 74-76.

González-Benito, M.E., Huertas-Micó, M. and Pérez-Garcia, F. (2006) Seed germination and storage of Chamaerops humilis (dwarf fan palm). Seed Science and Technology 34, 143-150.

Haccius, B. and Philip, V.J. (1979) Embryo development in Cocos nucifera L.: a critical contribution to a general understanding of palm embryogenesis. Plant Systematics and Evolution 132, 91-106.

Harper, J.L., Lovell, P.H. and Moore, K.G. (1970) The shapes and sizes of seeds. Annual Review of Ecology and Systematics 1, 327-356.

Henderson, F.M. (2006) Morphology and anatomy of palm seedlings. The Botanical Review 72, 273-329.

Hussey, G. (1958) An analysis of the factors controlling the germination of the seed of the oil palm, Elaeis guineensis (Jacq.). Annals of Botany 22, 259-284 +2 plates.

Janzen, D.H. (1982) Ecological distribution of chlorophyllous developing embryos among perennial plants in a tropical deciduous forest. Biotropica 14, 232-236.

Jiménez, V.N., Guevara, E., Herrera, J., Alizaga, R. and Bangerth, F. (2008) Changes in hormone concentrations during dormancy release of oil palm (Elaeis guineensis) seeds. Seed Science and Technology 36, 575-587.

Jordan, C.B. (1970) A study of germination and use in twelve palms of northeastern Peru. Principes 14, 26-32.

Jose, A.C., Erasmo, E.A.L. and Coutinho, A.B. (2012) Germinacão e tolerância á dessecação de sementes de bacca (Oenocarpus bacaba Mart.). Revista Brasileira de Sementes 34, 651-657.

Junior, A.G.R., Oliveira, T.G.S., de Souza, P.P. and Ribeiro, L.M. (2013) Water uptake and pre-germination treatments in the macaw palm (Acrocomia aculeata - Arecaceae) seeds. Journal of Seed Science 35, 99-105. 
Mabberley, D.J. (2008) Mabberley's plant-book. A portable dictionary of plants, their classification and uses (3rd edition). Cambridge, Cambridge University Press.

Megalhães, H.M., Lopes, P.S.N., Ribeiro, L.M., Sant'AnnaSantos, B.F. and Oliveira, D.M.T. (2013) Structure of the zygotic embryos and seedlings of Butia capitata (Arecaceae). Trees $27,273-283$.

Moore, H.E. Jr and Uhl, N.W. (1973) The monocotyledons: their evolution and comparative biology. IV. Palms and the origin and evolution of monocotyledons. The Quarterly Review of Biology 48, 414-436.

Moussa, H., Margolis, H.A., Dube, P.-A. and Odongo, J. (1998) Factors affecting the germination of doum palm (Hyphaene thebaica Mart.) seeds from the semi-arid zone of Niger, West Africa. Forest Ecology and Management 104, 27-41.

Myint, T., Chanprasert, W. and Srikul, S. (2010) Germination of seed of oil palm (Elaeis guineensis Jacq.) as affected by different mechanical scarification methods. Seed Science and Technology 38, 635-645.

Nagao, M.A. and Sakai, W.S. (1979) Effect of growth regulators on seed germination of Archontophoenix alexandrae. HortScience 14, 182-183.

Nagao, M.A., Kanegawa, K. and Sakai, W.S. (1980) Accelerating palm seed germination with gibberellic acid, scarification, and bottom heat. HortScience 15, 200-201.

Nazario, P., do Nascimento Ferreira, S.A., de Lima e Borges, E.E., Genovese-Marcomíni, P.R. and de Mendonça, M.S. (2013) Anatomical and histological aspects of the peach palm (Bactris gasipaes Kunth) seed. Journal of Seed Science 35, 171-178.

Neves, S.C., Ribeiro, L.M., Cunha, I.R.G., Pimenta, M.A.S., Mercadante-Simoes, M.O. and Lopes, P.S.N. (2013) Diaspore structure and germination ecophysiology of the babassu palm (Attalea vitrivir). Flora 208, 68-78.

Nikolaeva, M.G. (1999) Patterns of seed dormancy and germination as related to plant phylogeny and ecological and geographical conditions of their habitats. Russian Journal of Plant Physiology 46, 369-373.

Nikolaeva, M.G., Rasumova, M.V. and Gladkova, V.N. (1985) Spravochnik po prorashchivaniyu pokoyashckikhsya semyan (Reference book on dormant seed germination). Danilova, M.F. (Ed.). Leningrad, Nauka.

Orozco-Segovia, A., Batis, A.I., Rojas-Arechiga, M. and Mendoza, A. (2003) Seed biology of palms. Palms 47, 79-94.

Panza, V., Lainez, V. and Maldonado, S. (2004) Seed structure and histochemistry in the palm Euterpe edulis. Botanical Journal of the Linnean Society 145, 445-453.

Perez, H.E. (2009) Promoting germination in ornamental palm seeds through dormancy alleviation. HortTechnology 19, 682-685.

Perez, H.E., Criley, R.A. and Baskin, C.C. (2008) Promoting germination in dormant seeds of Pritchardia remota (Kuntze) Beck., an endangered palm endemic to Hawaii. Natural Areas Journal 28, 251-260.

Pinheiro, C.U.B. (2001) Germination strategies of palms: the case of Schippia concolor Burret in Belize. Brittonia 53, 519-527.
Pritchard, H.W., Wood, C.B., Hodges, S. and Vautier, H.J. (2004) 100-seed test for desiccation tolerance and germination: a case study on eight tropical palm species. Seed Science and Technology 32, 393-403.

Ribeiro, L.M., Souza, P.P., Rodrigues, A.G. Jr, Oliveira, T.G.S. and Garcia, Q.S. (2011) Overcoming dormancy in macaw palm diaspores, a tropical species with potential for use as bio-fuel. Seed Science and Technology 39, 303-317.

Ribeiro, L.M., Oliveira, D.M.T. and Garcia, Q.S. (2012a) Structural evaluations of zygotic embryos and seedlings of the macaw palm (Acrocomia aculeata, Arecaceae) during in vitro germination. Trees 26, 851-863.

Ribeiro, L.M., Oliveira, T.G.S., Carvalho, V.S., Silva, P.O., Neves, S.C. and Garcia, Q.S. (2012b) The behavior of macaw palm (Acrocomia aculeata) seeds during storage. Seed Science and Technology 40, 344-353.

Roberto, G.G. and Habermann, G. (2010) Morphological and physiological responses of the recalcitrant Euterpe edulis seeds to light, temperature and gibberellins. Seed Science and Technology 38, 367-378.

Robertson, B.L. (1976) Embryology of Jubaeopsis caffra Becc.: 3. Endosperm and embryogeny. Journal of South African Botany 42, 285-299.

Robertson, B.L. (1977) Morphology and development of the fruit and seed of Jubaeopsis caffra Becc. Principes 21, 23-30.

Robertson, B.L. and Small, J.G.C. (1977) Germination of Jubaeopsis caffra seeds. Principes 21, 114-122.

Schlindwein, G., Schlindwein, C.C.D., Tonietto, A. and Dillenburg, A.A. (2013) Alleviation of seed dormancy in Butia odorata palm tree using drying and moist-warm stratification. Seed Science and Technology 41, 16-26.

Tahir, S.M., Mu'azu, S., Khan, A.U. and Iortsuun, D.N. (2007) Studies on the germination and seedling characteristics of the savanna palm trees. Science World Journal 2, 25-31.

Tillich, H.-J. (2007) Seedling diversity and the homologies of seedling organs in the order Poales (Monocotyledons). Annals of Botany 100, 1413-1429.

Tomlinson, P.B. (1960) Essays on the morphology of palms. I. Germination and the seedling. Principes 4, 56-61.

Tomlinson, P.B. (1986) The botany of mangroves. Cambridge, Cambridge University Press.

Tomlinson, P.B. (1990) The structural biology of palms. Oxford, Oxford University Press.

Uhl, N.W. and Dransfield, J. (1987) Genera palmarum: a classification of palms based on the work of Harold E. Moore, Jr. The L.H. Bailey Hortorium and the International Palm Society. Lawrence, Kansas, Allen Press.

Von Fintel, G., Berjak, P. and Pammenter, N.W. (2004) Seed behavior in Phoenix reclinata Jacquin, the wild date palm. Seed Science Research 14, 197-204.

Wood, C.B. and Pritchard, H.W. (2003) Germination characteristics of fresh and dried Hyophorbe lagenicaulis seeds. Palms 47, 45-50.

Yakovlev, M.S. and Zhukova, G.Ya. (1980) Chlorophyll in embryos of angiosperm seeds, a review. Botaniska Notiser 133, 323-336. 